\title{
Effect of 3 Months of Doxazosin Therapy on T-cell Subsets in Type 2 Diabetic Patients
}

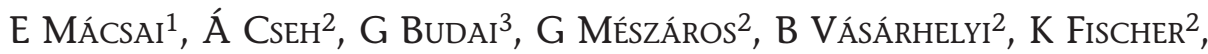 \\ A SZABÓ ${ }^{2}$ AND A TRESZL ${ }^{2}$
}
${ }^{1}$ Department of Internal Medicine, Csolnoky Hospital, Veszprém, Hungary; ${ }^{2}$ Research Group of Paediatrics and Nephrology, Hungarian Academy of Sciences, Budapest, Hungary;
${ }^{3}$ Department of Internal Medicine, Miskolc Healthcare Centre, Miskolc, Hungary

Doxazosin, an $\alpha_{1}$-adrenergic receptor inhibitor, is commonly administered to patients with type 2 diabetes, hypertension and nephropathy. The impact of 3 months' doxazosin therapy on the prevalence of activated and regulatory $\mathrm{T}$ lymphocytes was analysed in this pilot study of men with type 2 diabetes $(n=10)$ who received doxazosin $4 \mathrm{mg} /$ day in addition to their ongoing therapy. The prevalence of $\mathrm{CD}^{+}$, $\mathrm{CD}^{+}, \mathrm{CD}^{2} 5^{+}$and $\mathrm{CD}^{+} 9^{+}$cells at baseline and after 3 months of add-on therapy was determined. The prevalence of regulatory
T-cells was detected by two different approaches: forkhead box P3 (FoxP3) positivity; and the number of $\mathrm{CD} 4^{+} \mathrm{CD} 25^{\text {thigh }}$ cells. During 3 months of doxazosin therapy, patients' blood pressure, blood glucose control and lipid profiles all significantly improved. Simultaneously, the prevalence of activated T-cells $\left(\mathrm{CD}^{+} \mathrm{CD}^{+} 9^{+}\right.$and $\mathrm{CD}^{+}{ }^{+} \mathrm{CD} 69^{+}$cells) decreased, whereas that of regulatory $\mathrm{T}$ cells increased. These results indicate an immunomodulatory action of doxazosin in type 2 diabetic patients.

Key WORDS: Type 2 diabetes; Proteinuria; Doxazosin; $\alpha_{1}$-Adrenergic receptor inhibitor; IMMUNOMODULATION; LyMPHOCYTES; Regulatory T-CELls

\section{Introduction}

Current guidelines recommend the use of renin-angiotensin-aldosterone system (RAAS) inhibitors in diabetic patients with microalbuminuria. ${ }^{1}$ These agents prevent cardiovascular and renal morbidity ${ }^{2}$ and allcause mortality. ${ }^{3}$ The protection provided is proportional to the improvement of proteinuria. ${ }^{4}$ Some patients do not, however, respond sufficiently. This situation requires the introduction of another antihypertensive agent. ${ }^{5}$ Doxazosin, a selective $\alpha_{1}$-adrenergic receptor blocker, is used widely for this purpose as it improves morning surge hypertension, decreases albuminuria in patients with type 2 diabetes, ${ }^{6}$ and results in improvements of left ventricular mass index, plasminogen-activator inibitor-1 levels, lipid profiles, blood glucose control and endothelial dependent vasodilation. , $^{7}$

Studies have also reported immunomodulatory actions of doxazosin. For example, in hypertensive patients, high sensitivity C-reactive protein (hsCRP) has been shown to decrease after 4 months of doxazosin therapy. ${ }^{9}$ Doxazosin has also 
been shown to increase intracellular adhesion molecule-1 and CD40 expression, and interleukin-18 production by human peripheral monocytes, suggesting the modulation of innate immunity. ${ }^{10}$

There are no data on the impact of doxazosin on adaptive immunity. EpsteinBarr virus has been shown to transform B lymphocyte surface expression of $\alpha_{1}$ - and $\alpha_{2}$ receptors, ${ }^{11,12}$ providing a theoretical opportunity to study the immunomodulatory action of $\alpha_{1}$-adrenergic receptor blockers. Prazosin, another member of this pharmaceutical class, has been shown to delay the progression of autoimmune encephalitis (a T-cell mediated disorder) in animals. ${ }^{13}$

The present pilot study was designed to evaluate the effect of doxazosin on the prevalence of activated $\mathrm{CD}^{+}$and $\mathrm{CD}^{+} \mathrm{T}$ lymphocytes and regulatory $\left(\mathrm{CD}^{+}\right.$forkhead box $\mathrm{P} 3$ positive [FoxP3 $\left.{ }^{+}\right]$) T-cells (Treg cells) in patients with type 2 diabetes.

\section{Patients and methods PATIENTS}

Male patients with type 2 diabetes who regularly attended the Diabetes Outpatient Clinic of Miskolc Healthcare Centre, Miskolc, Hungary, were enrolled into this pilot study between March and May 2007. Inclusion criteria were persisting microalbuminuria (albumin excretion $\geq 30 \mathrm{mg} /$ day) and morning surge hypertension (blood pressure $>$ 130/85 mmHg). Patients with infection, malignancies or known allergies were excluded.

Each participant gave written informed consent. The study was carried out in accordance with the ethical standards of the Declaration of Helsinki (revised 1983) and the protocol was approved by the BAZ County Regional Ethical Council, Miskolc, Hungary.

\section{STUDY DESIGN AND ASSESSMENTS}

Patients' systolic and diastolic blood pressures and clinical chemistry were obtained at visit 1 , before administration of doxazosin $4 \mathrm{mg}$ once a day (Cardura ${ }^{\circledR}$ XL; Pfizer, New York, NY, USA), which uses a gastrointestinal therapeutic system (GITS) to provide a controlled rate of drug delivery into the gastrointestinal lumen. The dose regimens of any other drugs at baseline were to remain unchanged during the study. After 3 months of treatment, patients' blood pressure and clinical chemistry were reassessed (visit 2).

On visits 1 and 2, $5 \mathrm{ml}$ of blood was taken into commercially available heparincontaining tubes (BD Vacutainer ${ }^{\circledR}$; Becton Dickinson \& Co., Plymouth, UK). Peripheral blood mononuclear cells were separated from whole blood using a Ficoll-Paque ${ }^{\mathrm{TM}}$ Plus gradient (GE Healthcare Bio-Sciences, Uppsala, Sweden) within $6 \mathrm{~h}$ after sampling as previously described ${ }^{14}$ and stored at $-80^{\circ} \mathrm{C}$ until measurements were carried out (within 1 month). Patients' systolic and diastolic blood pressures and clinical chemistry, including glycated haemoglobin $\left(\mathrm{Hb}_{\mathrm{A} 1 \mathrm{C}}\right)$, total cholesterol, low-density lipoproteincholesterol (LDL-C), high-density lipoprotein-cholesterol (HDL-C) and triglyceride levels, microalbuminuria, high sensitivity C-reactive protein (hsCRP) plasma concentration, and estimated glomerular filtration rate (Cockcroft-Gault method), were assessed at both visits. At visits 1 and 2, measurement of intracellular FoxP3 and detection of CD4, CD8, CD25 and CD69 cell surface markers were performed as described previously. ${ }^{14}$ Blood pressure was measured at visits 1 and 2 by ambulatory blood pressure monitoring. For measurement of microalbuminuria, $200 \mathrm{ml}$ of 24 -h urine was used in an immunoassay method (Tinaquant albumin immunoturbidimetric assay (Roche Diagnostics, Basel, Switzerland). 


\section{STATISTICAL ANALYSIS}

The prevalence of different cell types before and after 3 months of doxazosin therapy was compared using the paired nonparametric Wilcoxon test. A $P$-value $<0.05$ was considered to be statistically significant. Statistical analysis were carried out using the ' $R$ ' software package (The ' $R$ ' Foundation for Statistical Computing, Vienna, Austria; http://www.r-project.org).

\section{Results}

A total of 10 men with type 2 diabetes were enrolled into this study. Their baseline clinical characteristics and baseline therapies are shown in Table 1.

Table 2 summarizes the impact of 3 months of therapy with doxazosin $4 \mathrm{mg}$ once a day on patients' cardiovascular risk profile and the various laboratory tests. At the end of the 3 months of therapy, morning surge hypertension, levels of $\mathrm{Hb}_{\mathrm{A1c}}$ total cholesterol and LDL-C, and microalbuminuria were significantly decreased $(P<0.05)$ compared with baseline levels. There were no significant changes in HDL-C, triglycerides, hsCRP and estimated glomerular filtration rate compared with baseline. There were marked changes in prevalence of the different immune cell types investigated, including statistically significant increases in $\mathrm{CD}^{+}{ }^{+} \mathrm{FoxP}^{+} / \mathrm{CD}^{+}$ $(P=0.009)$ and $\mathrm{CD} 4^{+} \mathrm{CD} 25^{\text {+high }} / \mathrm{CD} 4^{+}(P=$ $0.001)$ cell ratios, and statistically significant decreases in $\mathrm{CD}_{4}{ }^{+} \mathrm{CD} 69^{+} / \mathrm{CD} 4^{+}(P=0.003)$ and $\mathrm{CD} 8{ }^{+} \mathrm{CD} 69^{+} / \mathrm{CD}^{+}(P=0.022)$ cell ratios.

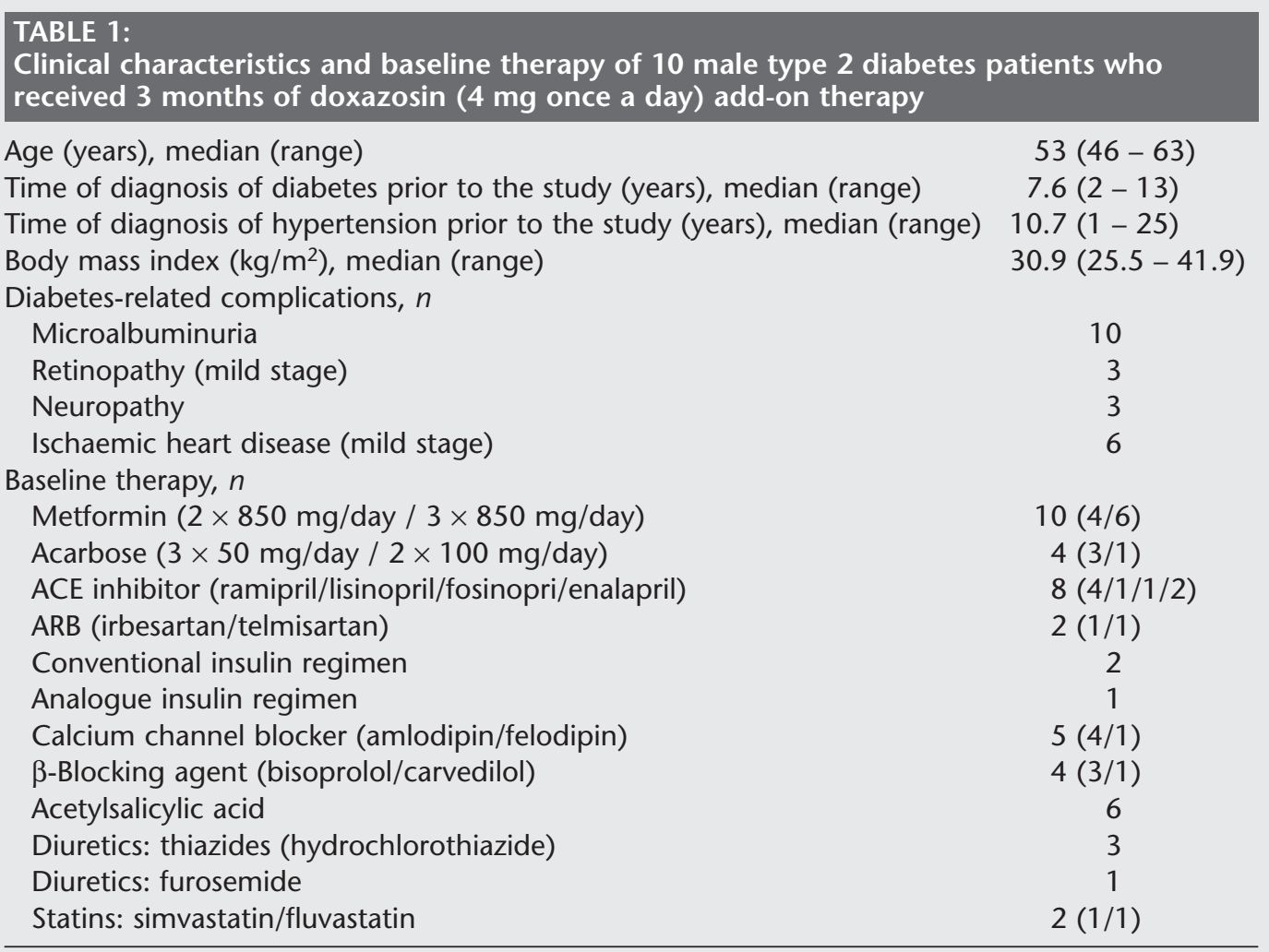

$\mathrm{ACE}$, angiotensin-converting enzyme; $\mathrm{ARB}$, angiotensin receptor blocker. 


\section{TABLE 2:}

Blood pressure, laboratory data, microalbuminuria and prevalence of investigated cell types in 10 male patients with type 2 diabetes measured before and after 3 months of doxazosin (4 mg once a day) add-on therapy

\begin{tabular}{|c|c|c|c|}
\hline Blood pressure and laboratory tests & $\begin{array}{l}\text { Before doxazosin } \\
\text { (visit 1) }\end{array}$ & $\begin{array}{l}\text { After } 3 \text { months of } \\
\text { doxazosin (visit } 2 \text { ) }\end{array}$ & $\begin{array}{c}\text { Statistical } \\
\text { significance }\end{array}$ \\
\hline \multicolumn{4}{|l|}{ Arterial blood pressure $(\mathrm{mmHg})^{\mathrm{a}}$} \\
\hline SBP between $08: 00 \mathrm{~h}$ and $21: 00 \mathrm{~h}$ & $134(111-192)$ & $128(100-157)$ & $P=0.022$ \\
\hline DBP between $08: 00 \mathrm{~h}$ and 21:00 $\mathrm{h}$ & $82(63-107)$ & $74(60-93)$ & $P=0.013$ \\
\hline SBP between $04: 00 \mathrm{~h}$ and $07: 00 \mathrm{~h}$ & $159(138-206)$ & $142(131-190)$ & $P=0.001$ \\
\hline DBP between $04: 00 \mathrm{~h}$ and 07:00 $\mathrm{h}$ & $97(82-129)$ & $80(71-101)$ & $P=0.002$ \\
\hline $\mathrm{Hb}_{\mathrm{A} 1 \mathrm{C}}(\%)$ & $7.65(5.2-9.0)$ & $6.70(4.9-8.9)$ & $P=0.013$ \\
\hline Total cholesterol (mmol/l) & $5.35(3.60-7.57)$ & $5.13(4.11-6.39)$ & $P=0.015$ \\
\hline LDL cholesterol (mmol/l) & $3.58(2.45-5.63)$ & $3.46(2.30-4.42)$ & $P=0.007$ \\
\hline HDL cholesterol (mmol/l) & $1.19(0.87-1.59)$ & $1.29(0.69-1.57)$ & NS \\
\hline Triglyceride $(\mathrm{mmol} / \mathrm{l})$ & $2.6(0.86-3.75)$ & $1.91(0.80-4.55)$ & NS \\
\hline \multicolumn{4}{|l|}{ Estimated GFR, Cockcroft-Gault } \\
\hline Microalbuminuria (mg/day) & $141.5(53-1125)$ & $9.5(3-548)$ & $P=0.013$ \\
\hline $\mathrm{hsCRP}(\mathrm{mg} / \mathrm{l})$ & $3.15(1.02-10.70)$ & $2.10(1.1-17.0)$ & NS \\
\hline \multicolumn{4}{|l|}{ Activated T-cell prevalence } \\
\hline $\mathrm{CD}^{+}{ }^{+} \mathrm{CD} 69^{+} / \mathrm{CD}^{+}$ & $2.32(1.28-4.01)$ & $0.61(0.40-2.50)$ & $P=0.003$ \\
\hline $\mathrm{CD}^{+}{ }^{+} \mathrm{CD} 9^{+} / \mathrm{CD}^{+}$ & $2.91(1.52-5.10)$ & $1.49(0.30-4.13)$ & $P=0.022$ \\
\hline \multicolumn{4}{|l|}{ Regulatory $\mathrm{T}$ cell prevalence } \\
\hline $\mathrm{CD}^{+}{ }^{+} \mathrm{CD} 25^{\text {thigh }} / \mathrm{CD}^{+}$ & $4.58(2.82-9.66)$ & $8.21(5.66-16.48)$ & $P=0.001$ \\
\hline $\mathrm{CD}^{+}{ }^{+} \mathrm{FoxP}^{+} / \mathrm{CD}^{+}$ & $1.92(0.04-4.73)$ & $4.59(1.07-9.09)$ & $P=0.009$ \\
\hline
\end{tabular}

Data are shown as median (range).

${ }^{a}$ Arterial blood pressure measured by $24-\mathrm{h}$ ambulatory blood pressure monitoring.

$\mathrm{SBP}$, systolic blood pressure; $\mathrm{DBP}$, diastolic blood pressure; $\mathrm{Hb}_{\mathrm{A1} c^{\prime}}$ glycated haemoglobin; $\mathrm{HDL}$, high-density lipoprotein; LDL, low-density lipoprotein; GFR, glomerular filtration rate; hsCRP, high sensitivity C-reactive protein; FoxP3, forkhead box P3; NS, not statistically significant $(P>0.05)$.

\section{Discussion}

The main finding of this pilot study was that 3 months of therapy with doxazosin $4 \mathrm{mg}$ once a day was associated with an improvement in cardiovascular risk factors and changes in adaptive immunity (a decrease in the prevalence of activated lymphocytes and an increase in the prevalence of regulatory $\mathrm{CD}^{+}$lymphocytes) in patients with type 2 diabetes.

The beneficial effects of doxazosin used as a second- or third-line agent on cardiovascular risk factors have been demonstrated in different hypertensive patient populations (including patients with diabetes, obesity and hypercholesterolaemia) in a large meta-analysis. ${ }^{15}$ Indeed, even in the small patient population used in the present study a significant decrease in morning surge and daytime hypertension was observed, as well as an improvement in proteinuria, lipid profile and blood glucose control. These findings are in line with previous observations. ${ }^{6,7}$

The immunomodulatory action of doxazosin is a novel observation. The pharmaceutical target of doxazosin, $\alpha_{1}$ adrenergic receptors, are expressed by not only the vascular wall, but also by a number of other tissues and cells, including 
lymphocytes. It has been suggested that $\alpha_{1}$ receptors play a role in the development of $\mathrm{T}$ lymphocytes in the thymus. ${ }^{16}$ In vivo, catecholamines inhibit the production of pro-inflammatory cytokines and contribute to the skewing of the immune system towards Th2 cell development. While lymphocyte function is predominantly modulated by $\alpha_{2}$-adrenergic receptors, ${ }^{17}$ it is thought that $\alpha_{1}$-adrenergic receptors may also play at least a partial role. ${ }^{18}$

The present study indicates that the prevalence of Treg cells, a lymphocyte subtype responsible for controlling the adaptive immune response, is increased after 3 months of doxazosin therapy in patients with type 2 diabetes. This increase in prevalence of Treg cells may be of major clinical importance. While the significance of low numbers of Treg cells in the progression and complications of atherosclerosis is supported by both animal and human data, ${ }^{19-21}$ no therapeutic approach exists to promote an increase in this particular cell type. The present study indicates that the modulation of adrenergic receptors in type 2 diabetic patients may be a way to produce higher numbers of Treg cells. The mechanism behind this phenomenon is, however, currently unclear; improved blood glucose control, immunomodulatory action on innate immune cells and/or even a direct effect on $\alpha_{1}$-adrenergic receptors may potentially contribute to an increase in the numbers of Treg cells.

As well as an increase in the number of Treg cells, the number of activated $\mathrm{CD}^{+}$and $\mathrm{CD}^{+}$T-cells decreased during doxazosin therapy in the present study. This may be characteristic of a systemic antiinflammatory action, although this was not reflected by the stable levels of hsCRP observed during the course of the study, which may have been due to a low baseline level. The limited data from the present study do not allow us to determine definitively whether this lower activation is due to an increased number of Treg cells, the result of the inhibition of $\alpha_{1}$-adrenergic receptors, or an improved metabolic state.

In conclusion, the present study indicates an immunomodulatory action of $\alpha_{1}$ adrenergic receptor inhibitor therapy in type 2 diabetic patients. Further studies are required to establish whether this effect contributes to protection against cardiovascular complications in this highrisk population.

\section{Acknowledgements}

This study was supported by grants OTKA76316 and OM0094-135-163/2008. A Treszl and B Vásárhelyi are recipients of a Bolyai Stipend.

\section{Conflicts of interest}

The authors had no conflicts of interest to declare in relation to this article.

- Received for publication 27 May 2009 • Accepted subject to revision 1 June 2009

- Revised accepted 9 October 2009

Copyright @ 2009 Field House Publishing LLP

References

1 American Diabetes Association: Standards of medical care in diabetes - 2007. Diabetes Care 2007; 30(suppl 1): S4 - S41.

2 de Zeeuw D, Remuzzi G, Parving $\mathrm{HH}$, et al: Albuminuria, a therapeutic target for cardiovascular protection in type 2 diabetic patients with nephropathy. Circulation 2004; 110: 921 - 927.

3 Jermendy G, Ruggenenti P: Preventing microalbuminuria in patients with type 2 diabetes. Diabetes Metab Res Rev 2007; 23: 100 110.

4 Basi S, Fesler P, Mimran A, et al: 
Microalbuminuria in type 2 diabetes and hypertension: a marker, treatment target, or innocent bystander? Diabetes Care 2008; 31(suppl 2): S194 - S201.

5 Cravedi P, Ruggenenti P, Remuzzi G: Does remission of renal disease associated with antihypertensive treatment exist? Curr Hypertens Rep 2007; 9: 160 - 165.

6 Kuriyama S, Otsuka Y, Iida R, et al: Morning blood pressure predicts hypertensive organ damage in patients with renal diseases: effects of intensive antihypertensive therapy in patients with diabetic nephropathy. Intern Med 2005; 44: 1239 - 1246.

7 Courtney $\mathrm{CH}$, McCance DR, Atkinson $\mathrm{AB}$, et al: Effect of the alpha-adrenergic blocker, doxazosin, on endothelial function and insulin action. Metabolism 2003; 52: 1147 - 1152.

8 Inukai T, Inukai Y, Matsutomo R, et al: Clinical usefulness of doxazosin in patients with type 2 diabetes complicated by hypertension: effects on glucose and lipid metabolism. J Int Med Res 2004; 32: 206 - 213.

9 Derosa G, Cicero AF, D'Angelo A, et al: Effect of doxazosin on C-reactive protein plasma levels and on nitric oxide in patients with hypertension. Cardiovasc Pharmacol 2006; 47: $508-512$.

10 Takahashi HK, Iwagaki H, Tamura R, et al: $\alpha_{1}$ Adrenergic receptor antagonists induce production of IL-18 and expression of ICAM-1 and CD40 in human monocytes. J Immunother 2005; 28: $40-43$.

11 Bubien JK, Cornwell T, Bradford AL, et al: $\alpha_{1}$ Adrenergic receptors regulate human lymphocyte amiloride-sensitive sodium channels. Am J Phys Cell Phys 1998; 275: C702 C710.

12 Veglio F, Tayebati SK, Schiavone D, et al: $\alpha_{1}$ Adrenergic receptor subtypes in peripheral blood lymphocytes of essential hypertensives. J Hypertens 2001; 19: 1847 - 1854.

13 Brosnan CF, Sacks HJ, Goldschmidt RC, et al: Prazosin treatment during the effector stage of disease suppresses experimental autoimmune encephalomyelitis in the Lewis rat. I Immunol 1986; 137: 3451 - 3456.

14 Svec P, Vásárhelyi B, Pászthy B, et al: Do regulatory $\mathrm{T}$ cells contribute to Th1 skewness in obesity? Exp Clin Endocrinol Diabetes 2007; 115: $439-443$.

15 Wykretowicz A, Guzik P, Wysocki H: Doxazosin in the current treatment of hypertension. Expert Opin Pharmacother 2008; 9: 625 - 633.

16 Plećas-Solarović B, Hristić-Zivković I, Radojević $\mathrm{K}$, et al: Chronic alpha1-adrenoreceptor blockade produces age-dependent changes in rat thymus structure and thymocyte differentiation. Histol Histopathol 2005; 20: 833 - 841.

17 Bao JY, Huang Y, Wang F, et al: Expression of $\alpha$ AR subtypes in T lymphocytes and role of the $\alpha$ ARs in mediating modulation of T cell function. Neuroimmunomodulation 2007; 14: 344 - 353.

18 Elenkov IJ, Wilder RL, Chrousos GP, et al: The sympathetic nerve - an integrative interface between two supersystems: the brain and the immune system. Pharmacol Rev 2000; 52: 595 638.

19 George J: Mechanisms of disease: the evolving role of regulatory $\mathrm{T}$ cells in atherosclerosis. Nat Clin Pract Cardiovasc Med 2008; 5: 531 - 540.

20 Mor A, Planer D, Luboshits G, et al: Role of naturally occurring $\mathrm{CD} 4{ }^{+} \mathrm{CD} 25^{+}$regulatory $\mathrm{T}$ cells in experimental atherosclerosis. Arterioscler Thromb Vasc Biol 2007; 27: 893 - 900.

21 Gotsman I, Grabie N, Gupta R, et al: Impaired regulatory T-cell response and enhanced atherosclerosis in the absence of inducible costimulatory molecule. Circulation 2006; 114: $2047-2055$.

Author's address for correspondence

Dr Barna Vásárhelyi

Research Group of Paediatrics and Nephrology, Hungarian Academy of Sciences, Semmelweis University, Bókay u. 53, Budapest 1083, Hungary.

Email: vasbar@gyer1.sote.hu 